\title{
PERSEPSI MAHASISWA TERHADAP PELAKSANAAN E-LEARNING DALAM MATA KULIAH MANAJEMEN SISTEM INFORMASI MAHASISWA JURUSAN TEKNOLOGI PENDIDIKAN UNIVERSITAS NEGERI MALANG
}

\author{
Seno Abi Yodha, Zainul Abidin, Eka Pramono Adi \\ Teknologi Pendidikan,Universitas Negeri Malang \\ Jalan Semarang 5 Malang 65145 0341-5747001 \\ Email: seno.abi7@gmail.com
}

\begin{tabular}{|c|c|}
\hline & Abstrak \\
\hline $\begin{array}{l}\text { Received:June 17, } 2019 \\
\text { Accepted:August 9, } 2019 \\
\text { Published:August 31, } \\
2019\end{array}$ & $\begin{array}{l}\text { Penelitian ini bertujuan untuk mengetahui persepsi mahasiswa teknologi } \\
\text { Pendidikan dalam menggunakan fasilitias e-learning yang meliputi antusias } \\
\text { mahasiswa saat pembelajaran, kelebihan dan kekurangan e-learning, dan } \\
\text { harapan mahasiswa terhadap e-learning. Rancangan penelitian ini adalah } \\
\text { penelitian kualitatif deskriptif. Subjek penelitian ini adalah mahasiswa } \\
\text { teknologi Pendidikan dalam menempuh matakuliah manajemen sistem } \\
\text { informasi. Hasil penelitian menunjukkan bahwa mahasiswa antusias dalam } \\
\text { menggunkan e-learning karena pembelajaran dilakukan secara online. } \\
\text { Mahasiswa merasakan bahwa jadwal yang digunakan dalam pemberian materi } \\
\text { atau tugas kurang terjadwal sehingga harapan mahasiswa adalah adanya } \\
\text { pemberian tugas yang terjadwal dan terstruktur. } \\
\text { Abstract } \\
\text { This study aims to determine the perceptions of students of Education } \\
\text { technology in using e-learning facilities that include student enthusiasm when } \\
\text { learning, the advantages and disadvantages of e-learning, and student } \\
\text { expectations towards e-learning. The design of this research is descriptive } \\
\text { qualitative research. The subjects of this study were students of Educational } \\
\text { technology in taking information systems management courses. The results } \\
\text { showed that students were enthusiastic in using e-learning because learning } \\
\text { was done online. Students feel that the schedule used in the delivery of material } \\
\text { or assignments is less scheduled so that the student's expectation is the } \\
\text { provision of scheduled and structured assignments. }\end{array}$ \\
\hline
\end{tabular}

\section{PENDAHULUAN}

Internet saat ini telah menjadi bagian yang tidak terpisahkan dari gaya hidup hampir semua kelompok masyarakat Indonesia salah satunya dalam bidang Pendidikan. Sesuai dengan perkembangan zaman yang selalu menggunaka teknologi, Pendidikan juga mengalami perkembangan dalam proses belajar mengajar yang dilakukan, salah satunya adalah melakukan pembelajaran berbasis teknologi atau menggunkaan internet. Namun akses terhadap laman pendidikan masih sangat kurang. Hal ini merupakan sebuah permasalahan yang perlu untuk disikapi oleh para pendidik dengan mengarahkan mahasiswa/peserta didik untuk lebih menggunakan internet dalam ranah pendidikan. Pembelajaran yang seperti ini sering disebut dengan pembeljaaran e-learning. Menurut Sabar (2011) e-learning adalah pembelajar-an dengan memanfaatkan teknologi elektronik sebagai sarana penyajian 
dan distribusi informasi. E-learning juga bisa disebut pembelajaran dalam jaringan atau Daring. Daring adalah pembelajaran yang dilakukan secara online melalui internet untuk mendukung pembelajaran tatap muka. Menurut Anggraini (2018) proses pembelajaran e-learning dapat dilakukan jarak jauh, tanpa harus bertatap muka di dalam ruangan secara langsung, dan waktu pembelajarannya pun lebih fleksibel

Berbagai layanan e-learning telah tersedia baik yang dikelola mandiri oleh institusi dengan menggunakan Learning Management System (LMS) maupun yang disediakan secara bebas oleh pihak ketiga. Universitas Negeri Malang telah memiliki e-learning yang dikembangkan dengan menggunakan LMS Moodle dan telah digunakan sebagai salah satu bentuk pembelajaran yang telah diakui oleh pimpinan Universitas Negeri Malang. Dosen di lingkungan TEP UM khususnya telah menggunakan e-learning, baik dalam bentuk unggah dokumen (RPS, Materi Perkuliahan) maupun dalam aktivitas pembelajaran secara daring seperti diskusi, dan pengumpulan tugas. Mahasiswa merupakan salah satu pihak yang merasakan pembelajaran menggunakan e-learning.

Kemauan seseorang dalam menggunakan produk teknologi sangat dipengaruhi oleh persepsi. Persepsi merupakan suatu proses yang dimulai dari pengguna panca indera dalam menerima stimulus, kemudian diorganisasikan dan diinterpretasikan sehingga memiliki pemahaman tentang apa yang diindera. Menurut Atkinson (dalam Desmita, 2013:107) persepsi adalah "proses dimana kita mengoranisasi dan menafsirkan pola stimulus dalam lingkungan. Penerapan e-learning pada kenyataannya masih banyaknya pro dan kontra, serta hasil lapangan, juga penelitian sebelumnya yang menyatakan anatara lain, masih kurangnya pemanfaatan media secara efektif yang menyebabkan tidak optimalnya penyerapan materi yang didapatkan, maupun kurang menariknya tampilan ataupun prosedur penggunaan yang menyebabkan mahasiswa kurang antusias.

Berdasaarkan paparan tersebut penelitian ini bertujuan untuk mengetahui respon mahasiswa jurusan teknologi pendidikan mengenai sistem pembelajaran e-learning yang di terapkan, khususnya pada mata kuliah manajemen sistem informasi. Dengan adanya penelitian ini juga diharapkan dapat membantu dosen pengampu mata kuliah yang berbasis e-learning sebagai evaluator kekurangan maupun kelebihan, serta menjadi sarana dan wadah dari harapan mahasiswa mengenai e-learning khusunya pada mata kuliah manajemen sistem informasi.

\section{METODE}

Metode penelitian ini adalah penelitian kualitatif deskriptif. Penelitian ini dilakukan di jurusan teknologi Pendidikan universitas negeri malang. Data yang diperoleh dalam penelitian ini adalah 1) antusias mahasiswa saat mengikuti pembelajaran menggunakan e-learning; 2) kelebihan dan kekurangan penggunaan e-learning dalam pembelajaran yang dirasakan oleh mahasiswa; 3) harapan mahasiswa tentang pembelajaran menggunakan e-learning. Berdasarkan paparan data yang akan dikumpulkan maka sumber data pada penelitian ini hanya terfokus pada mahasiswa yang menmpuh matakuliah Manajemen Sistem Informasi di pada tahun ajaran 2018/2019 di Universitas Negeri Malang. Teknik pengumpulan data yang digunakan adalah observasi dan wawancar untuk mengumpulkan data yang akan diteliti.

Setelah data terkumpul maka dilakukan analisis terhadap data yang diperoleh. Data mengenai antusias mahasiswa dianalisis dalam fokus kondisi lingkungan kelas, kegiatan pembelajaran, sistem aplikasi e-learning dan konten atau bahan ajar dalam e-learning. Data tentang kelebihan, kekurangan dan harapan mahasiswa akan dianalisis berdasarkan kegiatan pembelajaran yang dilakukan saat pelaksanaan e-learning dan konten pembentuk e-learning (meliputi infratruktur, sistem aplikasi dan konten)

\section{HASIL}

Berdasarkan penelitian yang dilakukan diperoleh data bahwa mahasiswa antusias saat instruktur menyampaikan arahan. Kondisi umum lingkungan kelas mendukung terlaksananya pelaksanaan e-learning yang ditunjukkan dengan adanya sistem registrasi dalam halaman logi-in yang 
sederhana. Hal ini sesuai dengan hasil wawancara yang menyatakan bahwa proses log-in hanya dilakukan dengan cara mengisi ID admin dan password saja. Mahasiswa menjadi antusias dalam mengikuti pembelajaran karena adanya peran dosen yang menunjang proses pembelajran dalam hal upload materi pembelajaran ataupun pemberian tugas hingga pemantauan pengerjaan tugas yang diberikan. Pemantauan tugas dilakukan secara online oleh dosen melalui website ataupun google docs.

Berdasarkan hasil observasi e-learning yang digunakan memiliki petunjuk penggunaan yang dapat membantu pengguna. Materi yang diajarkan telah tersedia dalam e-learning sehingga mahasiswa bisa belajar dimana saja dan kapan saja. Berdasarkan hasil wawancara mahasiswa antusias dalam mengerjakan tugas karena pengerjaan tugas dan pengumpulan tugas dilakukans ecara online sehingga menjadi efektif dan menghemat biaya pengeluaran akibat penegrjaan tugas. Proses pengumpulan tugas dilakukan dengan cara mengisi google form ataupun form yang tersedia dalam web site.

Mahasiswa antusias saat mengerjakan tugas, hal tersebut didukung dengan adanya kelengkapan fasilitas yang telah disediakan cukup menunjang pembelajaran, baik berupa hardware, maupun software. Berdasarkan hasil pengamatan, diketahui bahwa terdapat PC yang digunakan mahasiswa dalam pembelajaran yang compatible untuk mendukung kegiatan e-learning dalam pengerjaan tugas. Namun beberapa mahasiswa yang mengeluh akibat jaringan internet yang bisa dibilang kurang stabil, maupun mouse dan keyboard yang tidak pada tempatnya. Software pun tak ketinggalan mendukung dengan berupa tersedianya ruangan kelas dan peristiwa online, perangkat lunak program e-learning, konten pelatihan, konten yang memungkinkan menggunakan mouse, konten yang memungkinkan menggunakan keyboard, konten berbentuk teks. Evaluasi pelaksanaan elearning menunjukkan bahwa fasilitas yang ada dalam pembelajaran yang dilakukan dapat menunjang mahasiswa dalam belajar hal ini dikarenakan materi dalam pembelajaran cenderung mengarah pada pembelajaran yang bersifat praktik. Berdasarkan hasil wawancara mahasiswa dimudahkan belajar dengan e-learning karena belajar bisa dilakukan dimanapun dan mudah dalam mengakses materi pembelajaran yang disajikan di e-learning dalam bentuk soft file. Sistem dan aplikasi dalam e-learning memungkinkan mahasiswa mengunduh materi karena terdapat fitur upload ataupun download.

E-learning yanga ada di Jurusan Teknologi Pendidikan menggunakan strategi blended learning karena pembelajaran yang dilakukan adalah pembelajaran langsung maupun tidak langsung, serta metode yang digunakan diskusi, penugasan dll tergantung dari situasi dan kondisi lingkungan kelas maupun materi pembelajarannya. Pembelajaran yang dilakukan berinteraksi langsung dengan $e$ learning. Evaluasi diberikan dosen kepada mahasiswa berupa tugas akhir dan kuis. Kuis yang diberikan secara langusng saat mahasiswa dan dosen dapat bertatap muka.

Pelaksanaan e-learning memiliki kelebihan yaitu proses log-in yang sederhana memudahkan mahasiswa dalam memulai pembelajaran berbasis e-learning. Materi yang ada di e-learning telah disediakan sehingga mudah diakses oleh pengguna. Proses pengumpulan tugas dan pengerjaan tugas dilakukan secara online melalui google docs ataupun form sehingga efektif untuk dilakukan dan dapat menghemat biaya. Dengan adanya hal tersebut pembelajaran dilakukan dimana saja dan kapan saja. Pelaksanaan e-learning juga memiliki kekurangan yaitu adanya tampilan halaman login yang masih memtuhkan petunjuk lebih dalam. Materi yang diberikan kurang luas dan disajikan dalam bentuk Bahasa inggris sehinggga merepotkan mahasiswa dalam mempelajarinya. Adanya pengumpulan tugas yang tidak terjadwal serta tidak adanya pengawasan secara langsung atau face to face dalam pengerjaan tugas yang membuat pengumpulan tugas menjadi molor. Materi pembelajaran menjadi kurang dimengerti saat pembelajaran tidak ditunjang dengan penjelasan dosen secara langsung.

Kompenen pembentuk e-learning di jurusan teknologi Pendidikan memiliki kelebihan yaitu danya infrastruktur yang lengkap dengan sistem login yang sederhana. Materi yang ada dapat mudah diakses karena bahan ajar disediakan dalam bentuk soft file. Materi yang ada berupa text based yang dapat diakses menggunakan mouse maupun keyboard. Kelemahan dari komponen pembentuk elearning adalah adanya jaringan internet yang kurang stabil. Proes pemberian tugas yang tidak terjadwal dan dan materi yang diberikan berupa Bahasa inggris. Kerapihan infrastruktur juga dirasa kurang rapi oleh mahasiswa karena beberapa peralatan tidak berada sesuai dengan tempatnya.

Harapan mahasiswa terhadap pelaksanaan e-learning adalah adanya server dan jaringan internet yang stabil supaya login tidak eror serta danya perubahan tampilan login yang diberikan 
penjelasan lebih dalam. Mahasiswa berharap adanya penyajian materi pembelajaran yang lebih banyak dan tidak disajikan dalam bentuk bahasa inggris. Adanya penjadwalan pemberian tugas supaya pengerjaan tugas dan pengumpulan tugas menjadi tersetruktur dan tidak molor. Serta mahasiswa berharap adanya evaluasi setiap minggu dari adanya tugas yang telah dikerjakan oleh mahasiswa untuk mengetahui benar atau salahnya.

\section{PEMBAHASAN}

\section{Antuasias Mahasiswa dalam Pembelajaran Menggunakan E-Learning}

Mahasiswa antusias dalam mengikuti pembelajaran e-learning. Hal ini dilihat dari adanya fasilitas atau lingkungan belajar MSI yang menunjang dalam pembelajaran e-learning. Antusias mahasiswa dalam pembelajaran e-learning dikarena pembelajaran yang dilakukan lebih banyak prakteknya sehingga ruang leaboratorium beserta fasilitasnya atau infrastruktur dapat mendukung proses pembelajaran e-learning. Sesuai dengan pendapat Wirawan (2011) yang menyatakan ELearning terdiri dari dua macam, perangkat lunak komputer dan aplikasi berbasis web. Dari pernyataan tersebut diketahui bahwa e-learning terdiri dari komponen-komponen pembelajaran yang dapat menunjang pembelajaran berbasis web salah satunya adalah adanya jaringan internet. Pembelajran yang diakukan berbasis blended learning karena pembelajarn dilakukan menggunakan elearning yang ditunjang dengan pembelajaran langsung atau tatap muka. Sesuai dengan pendapat Bielawski \& Metcalf (dalam Hasamah, 2014) Blended learning adalah sebuah konsep yang relatif baru dalam pembelajaran di mana instruksi yang disampaikan melalui campuran pembelajaran online dan tradisional yang dalam pelaksanaannya dipimpin oleh instruktur atau pengajar

Mahasiswa antusias dalam menerima materi pembelajaran karena didukung adanya fasilitator atau dosen berperan penting dalam pembelajaran dengan melakukan pengunggahan materi, mengarahkan dan memantau proses pembelajaran. Hal ini sesuai dengan karakteristik pembelajaran e-learning. Menurut Ramdani (2014:397) menyatakan bahwa satah satu karakteristik pembelajaran $e$ learning adalah adanya peran Pengajar/lembaga pendidikan berfungsi sebagai mediator/pembimbing.

Berdasarkan hasil wawancara mahasiswa antusias saat pembelajaran karena bahan ajar atau materi mudah diakses secara online dan relevan untuk digunakan. Adanya materi yang diunggah memungkinkan adanya pembelajaran secara mandiri. Hal ini sesuai karakteristik e-learning dalam perguruan tinggi menurut Elyas (2018) yang menyatakan bahwa e-learning menggunakan bahan ajar bersifat mandiri (self learning materials) disimpan dikomputer sehingga dapat diakses oleh dosen dan mahasiswa kapan saja dan dimana saja bila yang bersangkutan memerlukan. Pendapat ini didukung dengan pendapat Khan (dalam Widhiartha, 2009) menyatakan bahwa e- learning dapat dilihat sebagai sebuah pendekatan inovatif untuk memberikan welldesign, berpusat pada peserta didik, interaktif, dan memfasilitasi lingkungan belajar kepada siapa pun, di mana pun, kapan saja dengan memanfaatkan sifat-sifat dan sumber daya dari berbagai teknologi digital bersama dengan bentuk lain cocok untuk bahan pembelajaranr terbuka, fleksibel dan didistribusikan lingkungan belajar

Mahasiswa terlihat antusias saat mengerjakan tugas dan mengumpulkan tugas karena proses pengerjaan dilakuakan secara online dan proses pengumpulan juga dilakukan secara online melalui link ataupun google form sehingga dapat menghemat biaya. Hal ini sesuai dengan pendapat Setiawan (2015) yang menyatakan bahwa pemanfaatan teknologi informasi memungkinkan pengajaran kepada mahasiswa lebih efisien dan dapat mengurangi biaya waktu serta tenaga dan lebih memudahkan berhubungan dengan mahasiswa dalam hal akademik. Dari paparan tersebut diketahui bahwa jenis $e$ learning yang digunakan adalah jenis asynchronous, menurut Effendy dan Zhuang (dalam Mutia, 2013) asynchronous adalah adalah mahasiswa dan dosen berada dalam waktu yang berbeda dalam proses pembelajaran sehingga mahasiswa dapat melakukan kegiatan pembelajaran setiap saat.

Berdasarkan hasil observasi yang dilakukan Pembelajaran manajemen informasi dilakukan dengan menerapkan pembelajaran yang berinteraksi langsung dengan program e-learning. Hal ini sesuai dengan pendapat Ramdani (2014:398) yang menyatakan bahwa pembelajaran e-learning dilakukan melalui media elektronik. Sehingga peserta didik dapat berinteraksi secara langsung dna belajar secara mendiri menggunakan e-learning. Dari pendapat tersebut menunjukkan bahwa elearning yang digunakan menggunakan jenis e-learning Synchronous training merupakan sebuah 
konsep yang kontradiktif dibanding dengan proses pembelajaran secara konvensional, yaitu mengeliminasi keberadaan kelas secara fisik menurut Donath (dalam Suranto 2009)

\section{Kelebihan dan kekurangan pelaksanaan e-learning}

Pelaksanaan e-learning pada matakulaih MSI di jurusan teknologi Pendidikan memiliki beberpa kelebihan. Proses log-in sangat memudahkan mahasiswa karena log-in dilakukan dengan mengisi ID admin dan langsung memasukkan password sehingga log-in dilakukan secara sederhana. Hal ini sesudia dengan pendapat Kardiana, dkk (2014) yang menyatakan bahwa lingkungan Learning Management System (LMS) yang menyatakan bahwa Penggunaan self-service dan layanan self-guided yang berarti peserta didik dapat melakukan registrasi secara mandiri ataupun dengan bimbingan pengajar. Kemudahan login yang digunakan juga sesuai dengan pendapat Elyas (2018) yang menyatakan bahwa syarat untuk mengembangkan e-learning adalah menggunakan prinsip sederhana yaitu memudahkan peserta didik dalam memanfaatkan teknologi dan menu yang ada, dengan kemudahan pada panel yang disediakan, waktu belajar peserta akan lebih efisien.

Berdasarkan hasil wawancara dengan beberapa narasumber menyatakan bahwa keuntungan dari pelaksanaan e-learning adalah mahasiswa menjadi lebih mudah dalam memperoleh materi dengan jelas karena terdapat fitur pengunduhan materi sehingga materi yang digunakan sudah tersedia dan relevan untuk digunakan. Hal ini sesuai dengan manfaat pembelajaran e-learning menurut menurut Novak (dalam Saifuddin, 2017) yang menyatakan bahwa pembelajaran e-learning dapat mempermudah dan menambah waktu interaksi antara mahasiswa dengan bahan belajar, serta mempermudah penyempurnaan dan penyimpanan bahan belajar. Materi yang disajikan dalam bentuk soft file sehingga memudahkan mahasiswa untuk mengakses. Sesuai dengan pendapat Alimuddin (2015) Manfaat penggunaan e-learning adalah mahasiswa juga dapat saling berbagi informasi dan dapat mengakses bahan-bahan ajar setiap saat dan berulang-ulang, dengan kondisi yang demikian itu mahasiswa dapat lebih memantapkan penguasaannya terhadap materi pembelajaran

Teknis pengerjaan tugas dan pengumpulan tugas menggunakan e-learning menurut mahasiswa juga memiliki kelebihan yaitu lebih efektif dan efisien karena menghemat biaya pengeluaran untuk mencetak tugas. Efeendi (2005) yang menyatakan bahwa keuntungan e-learning yang dirasakan adalah menghemat biaya, fleksibel atau bisa diakses dimana saja dan kapan saja. Berdasarkan hasil observasi dan wawancara diketahui bahwa pembelajaran menggunakan e-learning bisa dilakukan dimana saja dan kapan saja. Hal isi sesuai dengan pendapat yang dikemukakan Alimuddin (2015) Manfaat penggunaan e-learning adalah mahasiswa juga dapat saling berbagi informasi dan dapat mengakses bahan-bahan ajar setiap saat dan berulang-ulang, dengan kondisi yang demikian itu mahasiswa dapat lebih memantapkan penguasaannya terhadap materi pembelajaran.

Berdasarkan hasil wawancara dengan mahasiswa menunjukkan bahwa pelaksanaan e-learning dalam sistem registrasi memiliki tampilan login page yang masih membutuhkan penjelasan lebih dalam karena belum menunjukkan halaman untuk log-in. Hal ini sesuai dengan hasil penelitian menurut Elyas (2018) yang menyatakan bahwa Pengembangan e-learning tidak semata-mata hanya menyajikan materi pelajaran secara online, namun harus komunikatif dan menarik. Beberapa narasumber menyatakan bahwa materi yang ada di e-learning memiliki kekurangan seperti modul yang diberikan berupa bahasa inggris, sehingga mahasiswa menjadi repot dalam belajar untuk memahami materi. Hal ini sesuai dengan pendapat Mutia (2013) yang menyatakan bahwa dengan tidak adanya rutinitas yang ada di kelas, maka pelajar mungkin akan berhenti belajar atau bingung mengenai kegiatan belajar dan tenggang waktu tugas, yang akan membuat pelajar gagal.

Berdasarkan hasil wawancara mengenai proses pengumpulan tugas pada matakuliah maanjemen sistem informasi memiliki kekurangan yaitu pengumpulan tugas melalui e-learning tidak sesuai dengan batas waktu yang ditentukan atau pengumpulan tugas menjadi lambat karena pengumpulan tugas tidak terjadwal dan tidak dipantau secara face to face. Hal ini sesuai dengan pendapat Elyas (2018) yang menyatakan bahwa secara formal pemberian tes atau penugasan harus dialkukan sesuai jadwal yang ditentukan. sehingga pemberian tugas memang harus dituntut supaya diberikan secara terjadwal. 
Jaringan internet yang kurang stabil dapat menghambat proses pembelajaran menggunakan $e$ learning. Hal ini karena internet memiliki peranan penting dalam menunjang kelancaran pembelajaran menggunakan e-learning Keadaan ini sesuai dengan pernyataan Rosenberg (dalam Elyas 2018)

mengenai kriteria dasar dalam e-learning yaitu adanya penyampaian e-learning dikirimkan kepada pengguna melalui komputer dengan menggunakan standar teknologi internet.

\section{Harapan Mahasiswa tentang Pembelajaran Menggunakan E-Learning.}

Harapan mahasiswa dalam proses login adalah kemudahan dalam login atau adanya pengecekan server dan jaringan sehingga login bisa berjalan lancar dengan sistem akun pribadi atau kelompok supaya lebih mengetahui progress yang dicapai atau yang akan dilaksanakan serta adanya perubahan tampilan login yang lebih menarik. Harapan ini sesuai dengan pendapat ahli mengenai syarat e-learning dalam pembelajaran menurut Elyas (2018) yang menyatakan bahwa syarat $e$-learning adalah sederhana agar memudahkan pengguna dalam memanfaatkan teknologi dan menu yang ada.

Harapan mahasiswa mengenai infrastruktur adalah adanya perbaikan jaringan internet yang lebih dilancarkan serta adanya pengecekan infrastruktur sebelum memasuki ruang kelas dikarenakan berhubungan dengan kenyamanan mahasiswa dalam belajar dan keamanan perangkat-perangkat pembelajaran. Harapan ini sesuai dengan pengertian pembelajaran e-learning menurut Elliott Masie, cisco and comellia (dalam Munir 2009: 208) menjelaskan, e-learning adalah pembelajaran dimana bahan pembelajaran disampaikan melalui media elektronik seperti internet, intranet, satelit, TV, CDROM, dan lain-lain, jadi tidak harus internet karena internet salah satu bagian dari e-learning.

Harapan mahasiswa dalam hal proses pengunduhan materi adalah harapan mahasiswa terhadap materi yang akan digunakan dalam pembelajaran supaya memudahkan pembelajaran, sehingga materi yang diunggah adalah materi dengan Bahasa Indonesia dan bahan ajar diperbanyak lagi. Harapan ini kurang sesuai dengan teori karena pemberian materi dalam e-learning menuntut agar mahsiswa menjadi aktif dan tidak pasif. Hal ini sesai pendapat Alimuddin (2015) Manfaat penggunaan e-learning adalah dapat mempersingkat waktu pembelajaran dan mempermudah interaksi antara mahasiswa dengan dosen, maupun sesama mahasiswa.

Mahasiswa berharap adanya terjadwalnya materi yang diberikan, tugas yang diberikan terstruktur disertai adanya pemantauan dosen secara bertahap sehingga tugas yang diberikan tidak molor atau telat dan supaya lebih terarah. Hal ini sesuai dengan pendapat Elyas (2018) yang menyatakan bahwa secara formal pemberian tes atau penugasan harus dialkukan sesuai jadwal yang ditentukan. hal ini bertujuan supaya tugas yang diberikan menjadi efektif dan efisien untuk dikerjakan. Harapan mahasiswa tentang desain yang kurang menarik dan interaktif sangat sesuai dengan Elyas (2018) yang menyatakan bahwa Pengembangan e-learning tidak semata-mata hanya menyajikan materi pelajaran secara online, namun harus komunikatif dan menarik.

\section{SIMPULAN}

Mahasiswa antusias dalam melakukan pembelajaran menggunakan e-learning. Hal ini ditunjukkan dengan adanya infrastruktur yang sesuai dengan konseep e-learning yaitu menggunakan teknologi dan berbasis jaringan. Antusias mahasiswa dalam berlajar didukung dengan adanya fasislitator atau dosen dalam menunjang pembelajaran e-learning. Sehingga materi dan tugas yang diberikan mudah untuk diakses dimana saja dan kapan saja serta materi yang diberikan menjadi akurat. Fasilitator melakukan pemantauan secara online ataupun offline dalam pembelajaran. Pengumpulan tugas menjadi lebih hemat dan cepat sehingga pengerjaan tugas menjadi efektif dan efisien karena dilakukan secara online. E-learning yang dinggunakan strategi blended learning dengan metode yang bervariasi sesuai dengan materi yang diberikan hal ini ditunjukkan dengan adanya kuis dan evaluasi yang diberikan dosen secara langsung saat bertatap muka.

Pelaksanaan e-learning pada matakuliah manjemen sistem informasi memiliki kelebihan dan kekurangan. Keuntungan pelaksanaan e-learning yang dirasakan mahasiswa adalah adanya proses log-in yang sederhana, kemudahan memperoleh materi karena berbentuk sof file, dan pengerjaan maupun pengumpulan tugas menjadi lebih mudah dikarenakan dilakukan secara online dan dapat menghemat biaya. Mahasiswa dapat belajar di manasaja dan kapansaja. Kekurangan pelaksanaan e- 
learning adalah kurangnya penjelasan pada halaman login, materi berupa Bahasa inggris dan kurang luas, kurang adanya pemantauan secara langsung atau face to face karena pembelajaran masih membutuhkan pengarahan dari fasilitator secara langsung

Harapan mahasiswa terhadap pelaksanaan e-learning adalah diharapkan adanya pengecekan server dan jaringan sehingga memudahkan login ataupun proses pembelajaran. Diharapkan adanya perbaikan jaringan internet supaya pembelajaran menjadi lancer. Materi yang diberikan hendaknya menggunakan materi Bahasa Indonesia agar mudah dipahami dan materi yang diberikan diperbanyak sehingga mahasiswa memiliki banyak rujukan dalam belajar. Mahasiswa juga berharap adanya penjadwalan pemberian materi dan tugas supaya pembelajaran menjadi terarah. Mahasiswa berharap adanyatampilan e-learing yang didesain supaya lebih menarik dan interaktif. Serta mahaiswa berharap supaya materi yang diberikan tidak hanya berupa link melainkan ditunjang dengan materi yang berbentuk buku sehingga materi yang diberikan tidak membosankan

\section{REFERENSI}

Alimuddin., Tawany Rahamma., M. Nadjib. 2015. Intensitas Penggunaan E-Learning Dalam Menunjang Pemeblajaran Mahasiswa Program Sarjana (S1) Di Universitas Hasanuddin. Jurnal Komunikasi KAREBA, 4(4).

Anggraini, A. 2018. Keefektifan Pembelajaran Elektronik (E-Learning) Sebagai Pengganti Perkuliahan Konvensional Untuk Meningkatkan Kemampuan Analitis Mahasiswa. Jurnal Sosial Humaniora, 9(2), 95-105

Desmita. (2013).Psikologi Perkembangan. PT. Bandung :Remaja Rosdakarya.

Elyas, Ananda Hadi. 2018. Penggunaan Model Pembelajaran E-Learning Dalam Meningkatkan Kualitas Pembelajaran. Jurnal Warta, 56.

Hasamah. 2014. Pembelajaran Bauran (Blended Learning). Prestasi Pustaka Publiser.

Kardiana, Aan, Herika, Sri, Elan \& Nova. 2014. Kajian Penerapan Sistem E-Learning Dalam Proses Pembelajaran Di SLTA. Makalah Disajikan Dalam Seminar Nasional Aplikasi Teknologi Informasi (SNATI), Yogyakarta, 21 Juni 2014

Munir. 2009. Pembelajaran Jarak Jauh Berbasis Teknologi Informasi Dan Kominukasi. Bandung: Alfabeta.

Mutia, Intan \& Leonard. 2013. Kajian Penerapan E-Learning Dalam Proses Pembelajaran Di Perguruan Tinggi. Faktor Exacta, 6(4), 278-289 .

Ramdani, Ricky \& Eka Murdani. 2014. E-Learning Sebagai Media Pelengkap Pembelajaran Konvensional Pada Pokok Bahasan Besaran Dan Satuan. Prosidingpertemuanilmiah XXVIII HFI Jateng\& DIY, Yogyakarta, 26 April 2014

Sabar, Kurniawan., Asfah Rahman. Penggunaan Web (E-Learning) Dalam Proses Pembelajaran Bahasa Inggris Di Briton International English School Makasar. Junal Komunikasi KAREBA, 1(4), 444-456

Saifuddin, Much. Fuad. 2017. E-Learning Dalam Persepsi Mahasiswa. Varia Pendidikan, 29(2), 102-109

Setiawan, Dwi Lara Bagus., Siti Endang Astuti., Riyadi.2015. Pengaruh Penggunaan E-Learning Terhadap Kinerja Dosen Dalam Kegiatan Mengajar. Jurnal Administrasi Bisnis, 1(1)

Suranto, Beni. 2009. Virtual Classroom: Strategi Pembelajaran Berbasis Synchronous E-Learning. Makalah Disajikan Dalam Seminar Nasional Aplikasi Teknologi Informasi, Yogyakarta, 20 Juni 2009.

Widhiartha, Putu Ashintya. 2009. Pemanfaatan E-Learning Sebagai Alternative Pengganti Pelatihan Tatap Muka Bagi Pendidik Dan Tenaga Kependidikan Nonformal. Jurnal Ilmiah VISI PTK-PNF, 4(2), 189-196

Wirawan, Panji Wisnu. 2011. Pengembangan Kemampuan E-Learning Berbasis Web Ke Dalam M-Learning. Jurnal Masyarakat Informatika, 2(2), 21-26 